Nota preliminar

\title{
Clero y religiosidad en la España Moderna (ESTADOS DE LA CUESTIÓN)
}

Clergy and Religiosity in Modern Spain (States of the Question)

Ramón Maruri Villanueva Universidad de Cantabria

CESXVIII, núm. 27 (2017), págs. 9-10 DOI: https://doi.org/10.17811/cesxviii.27.2017.9-10
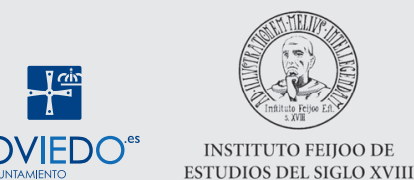

En todo peregrinaje a un lugar de culto es necesario, transcurrido un tiempo, detenerse a descansar y a hacer balance de lo andado y de lo por andar. No menos exige el peregrinaje a cualquiera de los ámbitos del conocimiento, que, en este caso, es el histórico. No se me ocurre mejor analogía — quizás por ser testigo del constante ir y venir de peregrinos actualmente por Cantabria, con motivo de la celebración del Año Santo Lebaniego- para definir lo que es un estado de la cuestión.

Han transcurrido ya, cuando menos, tres décadas desde que en las de 1970 / 1980 la historiografía modernista española conociera una radical transformación. El cambio social, como un todo que es, se plasmó en la Universidad española al incorporar a la docencia y a la investigación los conocimientos, conceptos y métodos vigentes en las naciones de nuestro entorno, de tal modo que, sin tardar mucho, el modernismo español pudo situarse en pie de igualdad al de los otros modernismos europeos.

Este monográfico, que me honra coordinar, es el alto en el camino, el momento de reflexionar sobre lo andado y lo por andar a que me he referido. La reflexión corre a cargo de cinco historiadores y dos historiadoras de diferentes universidades españolas, que han dedicado una parte fundamental de sus investigaciones a iluminar aspectos sustanciales de la Iglesia, la religión y la religiosidad en la España Moderna, campo este último que ocupa la mayor parte del monográfico. Independientemente de lo iluminador de sus contenidos, el monográfico aporta otro valor, como es el de su transversalidad.

Maximiliano Barrio Gozalo trata de quienes mejor representan a la Iglesia en sus múltiples dimensiones: el clero, tanto el secular como el regular, el masculino como el femenino, el alto como el bajo. Se interesa por lo aportado en materia de economía, articulación y jerarquización interna de los cleros secular y regular, poniendo el acento en las insuficiencias del conocimiento, por ejemplo, sobre el clero parroquial. Igualmente aborda el estado actual del conocimiento sobre la organización beneficial, la vida monasterial y conventual y el clero femenino, que tradicionalmente había sido poco atendido por los investigadores.

De cuestión hace ya un tiempo tan controvertida, no solo historiográficamente, como la del concepto de religiosidad, popular se ocupa Roberto J. López; controvertida no por lo que atañe al sustantivo, sino por la adjetivación de popular. Al tiempo que acota los términos del debate al respecto, traza el itinerario historiográfico de manifestaciones señeras de la religiosidad como son las ermitas y los santuarios, los exvotos y las reliquias, las rogativas, el movimiento misional popular, la predicación y la hagiografía. 
Como si de aceptar un reto que plantea este autor se tratara, Antonio Mestre Sanchis trata cuestión tan central en la España setecentista como la de la posición de los ilustrados ante algunas expresiones de la religiosidad por parte de la población española y también del clero, contemplando este eminentemente desde la perspectiva de su acción predicadora. Unos ilustrados que en su programa de renovación religiosa retomaban la reivindicación de los humanistas españoles de que la Iglesia concediera libertad para leer la Biblia en lengua vulgar.

De instituciones de carácter asociativo como eran cofradías y hermandades dan cuenta Inmaculada Arias de Saavedra Alías y Miguel L. López-Guadalupe Muñoz. Subrayan de ellas su masiva expansión por todo el territorio español en los siglos modernos. La perspectiva de historiadores sociales desde la que abordan el análisis desvela el carácter plurifuncional de ambas instituciones, lo que les permite fijar su tipología. Subrayan igualmente, junto a la especificidad del movimiento congregacional, la tensión que se genera entre la vocación autonómica cofradiera y el atento control que sobre cofradías y hermandades ejercían los poderes monárquico y eclesiástico.

M. José de la Pascua establece la andadura historiográfica de uno de los campos más atendidos en la historiografía modernista española sobre las mentalidades, el de la dimensión socio-religiosa de la muerte. Aporta unas reflexiones iluminadoras sobre cuestiones ya de irrenunciable tratamiento: el espacio, tanto físico como simbólico, el tiempo, los ritos, los gestos, los discursos, los contrastes regionales o las fuentes. Nucleares son, igualmente, sus consideraciones en torno a los procesos de implantación y disolución del modelo barroco de muerte.

Por último, quien esto escribe se interesa por las devociones religiosas, uno de los componentes de la religiosidad. Incide en cómo las aportaciones de la Antropología han enriquecido el análisis histórico, de tal modo que este ha de partir ya, como así sucede, de las exigencias de los sistemas complejos. Es así que la devoción a un ser sagrado ha dejado de ser observada desde la unidimensionalidad de lo estrictamente religioso para serlo como un objeto de conocimiento con múltiples planos de significación, apelándose a la necesidad de trascender la escala local y de enmarcar los análisis en la historia comparada.

Tan solo me resta agradecer al Instituto Feijoo de Estudios del Siglo XVIII, a través de la directora de Cuadernos de Estudios del Siglo XVIII, la Dra. Elena de Lorenzo Álvarez, el reconocimiento que me hacen al haberme propuesto coordinar este monográfico. E igualmente quiero agradecer a mis queridos colegas participantes en él haber aceptado, a su vez, mi invitación a que compartieran con la comunidad de lectores la densidad de sus saberes en los temas que cada uno de ellos trata. 